\title{
Intangible Property: Protection of Virtual Property in Electronic Games in China and US
}

\author{
Hanyue Wang ${ }^{*}$ \\ Illinois Institute of Technology Chicago-Kent College of Law, US
}

\begin{tabular}{|c|c|}
\hline ARTICLE INFO & ABSTRACT \\
\hline Article history & \multirow{13}{*}{$\begin{array}{l}\text { With blossoming of the electronic games, the strategy of game developer } \\
\text { preference is that the player uses real money to buy the virtual property in } \\
\text { the game. The purpose for the strategy which keeping the game promote } \\
\text { and developing the game system on the platform to attract more users. } \\
\text { With the increasing amount of game, the main strategy is same. The } \\
\text { chain, the End User License Agreement (EULA) which between the game } \\
\text { developer and player is vital. EULA used to rule that the virtual property } \\
\text { is belong to the game developer. However, for now, the virtual property } \\
\text { has different acquisition way, "all virtual property belongs to the develop- } \\
\text { er" since already unfair. } \\
\text { Staring from the first virtual property lawsuit in China, this paper intro- } \\
\text { duces the virtual property of electronic game and legal protection in US } \\
\text { and China. Second, discussion the reasons to protection virtual property } \\
\text { and provide proposals for a potential legislative solution in China. At the } \\
\text { end, this paper presents the reason that copyright law not suitable to pro- } \\
\text { tect the virtual property. }\end{array}$} \\
\hline Received: 25 March 2020 & \\
\hline Revised: 7 April 2020 & \\
\hline Accepted: 9 October 2020 & \\
\hline Published Online: 16 October 2020 & \\
\hline Keywords: & \\
\hline Virtual property & \\
\hline Electronic game & \\
\hline User license agreement & \\
\hline Legislative solution & \\
\hline Pronerty law & \\
\hline Property raw & \\
\hline Copyright law & \\
\hline
\end{tabular}

\section{Introduction}

A company cannot kill the virtual asset trading industry, OPSkins said. ${ }^{(1)}$ OPSkins is the world's largest third-party trading platform, but also out of 50 billion dollars of fat every year. OPSkins quickly became the largest secondary market in Steam's game asset community by virtue of its own advantages, which is undoubtedly a robbery for Steam. ${ }^{2}$ Valve, the parent company of Steam, the world's largest digital game distribu-

(1) Arielle, Official Statement Regarding Valve \& OPSkins Steam Accounts, OPSKINS (Jun 09, 2018), http://blog.opskins.com/official-statement-regarding-valve-opskins-steam-accounts/.

(2) Arielle, Official Statement Regarding Valve \& OPSkins Steam Accounts, OPSKINS (Jun 09, 2018), http://blog.opskins.com/official-statement-regarding-valve-opskins-steam-accounts/.

*Corresponding Author:

Hanyue Wang,

Research direction: intellectual property;

Illinois Institute of Technology Chicago-Kent College of Law, US; E-mail:530550578@qq.com. tion platform, banned OPSkins trading robots on June 21, 2018. ${ }^{3}$ In order to change the current dilemma, OPSkins chose to start the block chain project - preparing to start WAX Trade. (4) It has to say that the free trade of virtual property has already appeared, which the general trend is. But the ownership of virtual property is still be tortured by EULA. (5)

(3) Arielle, Official Statement Regarding Valve \& OPSkins Steam Accounts, OPSKINS (Jun 09, 2018), http://blog.opskins.com/official-statement-regarding-valve-opskins-steam-accounts/.

(4) Arielle, Official Statement Regarding Valve \& OPSkins Steam Accounts, OPSKINS (Jun 10, 2018), http://blog.opskins.com/official-statement-regarding-valve-opskins-steam-accounts/.

(5) Arielle, Official Statement from OPSkins Regarding the Future of Digital Item Trading, OPSKINS (Jun 11, 2018), http://blog.opskins.com/ official-statement-from-opskins-regarding-the-future-of-digital-itemtrading/. 
In China, 2003, Hongchen Li prosecuted Arctic Ice; the cause was that Li's properties related to the game was lost because of the third-party software (plug-in) he used; Hongchen Li brought an action against the game developer to recover his game equipment. This is the first case related to virtual game in China. The court deemed that the developer had obligation of contract to protect the player property, but the property related to the game could not be measured through actual currency, so Arctic Ice should help the accuser to regain his game property except which damage caused by plug-in. ${ }^{(1)}$

Since "the first case about virtual property", virtual social space becomes increasingly mature as information technology is developing; online game industry has shown

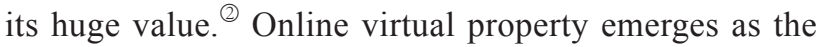
online game develops, and it is significant for both game developer and players. ${ }^{3}$ It is normal to exchange virtual properties in network world that items related to game from equipment to ID could be bought with actual currency because they are sold on marked price; some people even live on playing game for others. As online game is creating huge market value, a series of disputes related to online virtual property occur. Till 2016, China did not have any legislation which admitted virtual property. Regulations about virtual property were normally shown to player through End User License Agreement (EULA), which stipulated that virtual property belonged to game developer, and game developer had right to reserve all rights. Until 2017 when General Rules of the Civil Law of the People's Republic of China was enacted, the Article 127 stipulates: "Provisions should be followed once there are provisions related to protect data and online virtual property." ${ }^{\oplus}$ This is the first time for China to admit that virtual property is protected by law in the form of written law. However, what is the nature of virtual property? What is its scope? Does it belong to players or developers? What kind of legal system should be used to protect it? All of these are not clear.

(1) Li Hongchen Su Beijing Arctic Ice Technology Development Co., Ltd. [Li Hongchen v. Beijing Arctic Ice Technology Development Co., Ltd.], 2004 Beijing Second Intermediate People's Ct. Dec 17, 2004).

(2) Hu Yifeng, Nian Nian Mianbi Tu Po BI: Woguo Wangluo Youxi Yanjiu (1998-2018) de Guiji, Fanshi Yu Quxiang Twenty Years of Wall Breaking: Track, Paradigm and Trend of China's Online Game Research (1998-2018)] Article Judgement]22-23 (10, 2018).

(3) Hu Yifeng, Nian Nian Mianbi Tu Po BI: Woguo Wangluo Youxi Yanjiu (1998-2018) de Guiji, Fanshi Yu Quxiang Twenty Years of Wall Breaking: Track, Paradigm and Trend of China's Online Game Research (1998-2018)] Article Judgement]22-23 (10, 2018).

(4) Zhonghua Renming Gongheguo Minfa Zongze [General Provisions of the Civil Law of the People's Republic of China] (promulgated by the National People's Congress., Mar. 15, 2017, effective Oct 1, 2017) 2017 Standing Comm. Nat'l People's Cong. Gaz. 127 (China).
In the last few years, a new form of valuable "property" has been emerging. Property created and used in the virtual realm of video games is often given real-world value, and as a result, there has a bridge between the virtual economies with real-world market. Despite its intangible nature, the virtual property can carry physical and intellectual property rights both. Normally, the developers of electronic gaming worlds generally retain these rights via ELUA. In the past, those agreements have been held to be enforceable. However, policy reasons may be emerged. The part I describes the problem the legislator need to consider how to treat the ownership of virtual property and whether they can divide rights only under the EULA.

To understand the concept of virtual property, that is important for us to divide with the real property. "Normally, virtual property is simply computer code."(3) The computer content have different expression of codes. The represent of virtual property computer code is "designed to act more like land or chattel". ${ }^{\circ}$ The original virtual properties in the online world included "domain names, URLs (uniform resource locators), websites, [and] e-mail accounts" $\gg$ Such property "consists of computer code and it can be sold among entities." ${ }^{\circledR}$ The virtual property in electronic game is equipment, virtual coin, role of game players and so on. ${ }^{(9)}$

Not only in China, but also around the world, because of the development of major virtual games and the improvement of public acceptance, the target audience of virtual property is not small. The Virtual worlds is more often referred to as Massive Multiplayer Online Role-Playing Games (MMORPGs). Today, the virtual world has surpassed any expectations to enter the main Entertainment Centers: Some of them are 'virtual homes' for hundreds of thousands or even millions of subscribers, and the most famous World of Warcraft reaches 7,5 million (Blizzard Entertainment, 2006). The numbers have transformed them from a simple combat-oriented game to a mature virtual environment where players participate in various social activities. As expected, it has attracted people's attention for future potential of these virtual environments raises the question of how to treat the virtual world legally. The virtual world has changed from a pure game to a virtual place

\footnotetext{
(5) Joshua Fairfield, "Virtual Property" (2005) 85 B.U.L. Rev. 1047 at 1049 .

(6) Joshua Fairfield, "Virtual Property" (2005) 85 B.U.L. Rev. 1047 at 1049 .

(7) Joshua Fairfield, "Virtual Property" (2005) 85 B.U.L. Rev. 1047 at 1049 .

(8) Joshua Fairfield, "Virtual Property" (2005) 85 B.U.L. Rev. 1047 at 1049 .

(9) Joshua Fairfield, "Virtual Property" (2005) 85 B.U.L. Rev. 1047 at 1049 .
}

DOI: https://doi.org/10.26549/jfr.v4i2.3752 
where people work or create culture, so they have reasonable expectations for the virtual products of their labor. ${ }^{\mathbb{1}}$

For the cases of virtual property disputes, the courts can directly show how to judge whether virtual property is of real value in the process of practice in various countries. In Black snow Interactive v. Mythic Entertainment Inc., Black snow Interactive, a small development company. ${ }^{\circledR}$ They rented office space in Tijuana, equipped with computers and T1 lines, and hired three Mexican laborers to play online computer games from punch to exit time. ${ }^{3}$ The games they need to play are Camelot in the Dark Ages of the Ultima Online Desert, which are online massively multiplayer role-playing games. ${ }^{\oplus}$ When workers operate their characters in the game, they can earn the skill and gold. Black snow calculates the wages of the workers in piece count, then they sell senior characters and makes money on eBay. ${ }^{(5)}$ The Grandmaster Grayson-tamer account from Ultima is sold for $\$ 200$. $^{\odot}$ However, developer found this situation and closed the game account. ${ }^{\circledR}$ The issue in the case: Who own the game equipment? Developer or players?

In the example cases, this is the first case about virtual property in U.S history, "the Black snow was lost in the case. The Federal Trade Commission did not support Black snow's defense but fined it for $\$ 10000 .{ }^{\circledR}$ Under the case, Ed Felton, a Princeton professor notes that "our world becomes increasingly virtual, more over our property will become virtual — and increasingly under copyright protection.. ${ }^{\circledR}$ As owners of virtual property, Felton argues, "we need to start challenging its privileges as intellec-

(1) oshua Fairfield, "Virtual Property" (2005) 85 B.U.L. Rev. 1047 at 1049 .

(2) Black Snow Interactive and the World's First Virtual Sweet Shop, JULIAN DIBBELL (Jan 2019), http://juliandibbell.com/texts/blacksnow. $\mathrm{html}$.

(3) Black Snow Interactive and the World's First Virtual Sweet Shop, JULIAN DIBBELL (Jan 2019), http://juliandibbell.com/texts/blacksnow. html.

(4) Black Snow Interactive and the World's First Virtual Sweet Shop, JULIAN DIBBELL (Jan 2019), http://juliandibbell.com/texts/blacksnow. html.

(5) Black Snow Interactive and the World's First Virtual Sweet Shop, JULIAN DIBBELL (Jan 2019), http://juliandibbell.com/texts/blacksnow. html.

(6) Black Snow Interactive and the World's First Virtual Sweet Shop, JULIAN DIBBELL (Jan 2019), http://juliandibbell.com/texts/blacksnow. html.

(7) Black Snow Interactive and the World's First Virtual Sweet Shop, JULIAN DIBBELL (Jan 2019), http://juliandibbell.com/texts/blacksnow. $\mathrm{html}$.

(8) Black Snow Interactive and the World's First Virtual Sweet Shop, JULIAN DIBBELL (Jan 2003), http://juliandibbell.com/texts/blacksnow. $\mathrm{html}$.

(9) Black Snow Interactive and the World's First Virtual Sweet Shop, JULIAN DIBBELL (Jan 2019), http://juliandibbell.com/texts/blacksnow. html. tual property". ${ }^{\circledR}$ However, the United States have more favored to protect virtual property as a legal property. Therefore, the End User License Agreement (EULAs) are especially important for the protection of virtual property.

In China, the first case about the virtual property, the court hold that virtual property cannot be compensated equally by real money. In Li Hongchen v. Beijing Arctic Ice Technology Development Co., Ltd., the service contract dispute between the player and the game developer was provoked due to an online game in the case of $\mathrm{Li}$ Hongchen (hereinafter referred to as "Li") suing Beijing Beijibing Science and Technology Development Co., Ltd. (hereinafter referred to as "Beijibing"). ${ }^{\mathbb{1}}$

This court confirmed the evidence submitted by $\mathrm{Li}$ and further affirmed that the regulations of Red Moon had failed to be presented in an appropriate manner when the player entered into this game for the first time. ${ }^{(1)}$ Due to the fact that the notarial deed provided by the company failed to certify the situation at that time, the regulations of Red Moon should not be regarded as a contract signed between the two parties and the legal basis for the rights and obligations of both parties. ${ }^{(-)}$Obviously, for gamers, such result is not enough to make them satisfied.

For short mention, the key question is whether the EULA should allow the player become owner? Basic on the 30 cases in China, we can clearly see the rules of EULA is not equal. The EULAs are usually a threshold for developers before players enter the game. It can be said to be the key to open the virtual world door for games. The content of the agreement stipulates the rights and obligations between the developer and the player. For example: The World of Warcraft: The company reserves any rights to the game. ${ }^{\circledR}$ Players don't care about this rule when they first enter the virtual world, but as the player's input into the game consumes energy, the player's expectation of the game is much more than just

(10) Black Snow Interactive and the World's First Virtual Sweet Shop, JULIAN DIBBELL (Jan 2019), http://juliandibbell.com/texts/blacksnow. html.

(11) Li Hongchen Su Beijibing Arctic Ice Technology Development Co., Ltd. [Li Hongchen v. Beijbing Arctic Ice Technology Development Co., Ltd.], 2004 Beijibing Second Intermediate People's Ct. Dec 17, 2004).

(12) Li Hongchen Su Beijibing Arctic Ice Technology Development Co. Ltd. [Li Hongchen v. Beijbing Arctic Ice Technology Development Co. Ltd.], 2004 Beijibing Second Intermediate People's Ct. Dec 17, 2004).

(13) Li Hongchen Su Beijibing Arctic Ice Technology Development Co., Ltd. [Li Hongchen v. Beijbing Arctic Ice Technology Development Co., Ltd.], 2004 Beijibing Second Intermediate People's Ct. Dec 17, 2004).

(14) Blizzard End User License Agreement, North America (Jun. 1, 2018), https://www.blizzard.com/en-us/legal/fba4d00f-c7e4-4883-b8b91b4500a402ea/blizzard-end-user-license-agreement (last visited Apr.28, 2019). 
the time they first entered. ${ }^{\mathbb{D}}$ They hope to sell Game account in the real world, buy other players' equipment use real money. ${ }^{(2)}$ They are in order to upgrade quickly, get more rewards in the game. ${ }^{(3)}$

Beside we can change the owners of virtual property in EULA, we also can argue whether the copyright law can provide protect for it.

Currently, the China legal system is hard to support the argument. General Rules of the Civil Law of the People's Republic of China, the article 123(2) have limit for subject matter of intellectual property, all subject have the common both are intellectual achievements. ${ }^{\oplus}$ However, I can't denied that the produce of virtual property is similar with Bitcoin. Bitcoin requires "miners" to compete for accounting rights in a specific time. Because the randomness of the Hash Algorithm itself, the computing power of "miners" is required, but the result are hardly to see have any human intelligence. ${ }^{(9)}$

The creation of virtual property comes from the date provided by the game itself. Take Second Life as an example, when developers attract game players into the game, they have said that the virtual land property you create in the game belongs to their players, and the players have the right to make profits through the virtual property. ${ }^{\odot}$ Players actually pay a certain amount of real money to Linden when they acquire the virtual property of the game. Players are free to buy virtual land, build homes and islands, and other players need to pay a certain amount of money to enter the field.

(1) Michael H. Passman, Transactions of Virtual Items In Virtual Worlds, Albany Law Journal of Science and Technology, 261-290, 268, https://www.westlaw.com/Document/I2f794a998a8e11dd93e7a76b30106ace/View/FullText.html?transitionType=Default\&contextData $=($ sc. Default $) \& V R=3.0 \& R S=$ cblt1.0.

(2) Michael H. Passman, Transactions of Virtual Items In Virtual Worlds, Albany Law Journal of Science and Technology, 261-290, 269, https://www.westlaw.com/Document/I2f794a998a8e11dd93e7a76b30 $106 \mathrm{ace} /$ View/FullText.html?transitionType $=$ Default\&contextData $=($ sc . Default $) \& V R=3.0 \& R S=$ cblt 1.0 .

(3) Michael H. Passman, Transactions of Virtual Items In Virtual Worlds, Albany Law Journal of Science and Technology, 261-290, 272, https://www.westlaw.com/Document/I2f794a998a8e11dd93e7a76b30 106ace/View/FullText.html?transitionType $=$ Default\&contextData $=($ sc . Default) \&VR=3.0\&RS=cblt1.0.

(4) Zhonghua Renming Gongheguo Minfa Zongze [General Provisions of the Civil Law of the People's Republic of China] (promulgated by the National People's Congress., Mar. 15, 2017, effective Oct 1, 2017) 2017 Standing Comm. Nat'1 People's Cong. Gaz. 123(2) (China).

(5) Reuben Grinberg, Bitcoin: An Innovative Alternative Digital Currency, 4 Hastings Sci. \& Tech. L.J. 159, 163 (2012). https://www. westlaw.com/Document/Id470bb002b9e11e18b05fdf15589d8e8/ View/FullText.html? transitionType $=$ Default\&contextData $=($ sc.Default) $\& \mathrm{VR}=3.0 \& \mathrm{RS}=$ cblt1.0.

(6) John D. Sutter, CNN, Can People actually 'own'virtual land? (May. 20, 2010), http://www.cnn.com/2010/TECH/05/10/virtual.property.second.life/index.html (last visited Apr. 14, 2019).
But at present, if only on the basis of the game itself, the virtual property types that the game itself does not provide are not original. Because no matter how the player manufactures it, it all comes from the game date provided by the developer.

Based on the analysis above, I think the virtual property itself cannot be the object of copyright protection for the following reasons: first, in China, the object of copyright protection is literary, artistic and scientific works, and these works should be original, and can be copied in some tangible way. Secondly, the time limit of copyright protection object is more harmful than beneficial to the rapid development of game business. Thirdly, assuming that a virtual property can be protected by copyright law, copyright law protection easily delays, which can easily limit the development of game and the enthusiasm of developers. Therefore, in this scenario, the current Chinese law and even the United States cannot be recognized, the copyright law cannot protect the virtual property. However, we can make a presumption, If the future game allows certain players to develop their own, players can use formulas to create original data to load the game, then create virtual property, and be allowed to enter the game by developers. I think it may can be the protection object of this kind of virtual property type of formulas as copyrightable. However, the dates cannot be protectable by copyright law, but the player who design the game role weapons and clothes may can be protectable by copyright law.

\section{References}

[1] Arielle, Official Statement Regarding Valve \& OPSkins Steam Accounts, OPSKINS (Jun 09, 2018), http://blog.opskins.com/official-statement-regarding-valve-opskins-steam-accounts/.

[2] Hu Yifeng, Nian Nian Mianbi Tu Po BI: Woguo Wangluo Youxi Yanjiu (1998-2018) de Guiji, Fanshi Yu Quxiang Twenty Years of Wall Breaking: Track, Paradigm and Trend of China's Online Game Research (1998-2018)] [Article Judgement] 22-23 (10, 2018).

[3] Zhonghua Renming Gongheguo Minfa Zongze [General Provisions of the Civil Law of the People's Republic of China] (promulgated by the National People's Congress., Mar. 15, 2017, effective Oct 1, 2017) 2017 Standing Comm. Nat'l People's Cong. Gaz. 127 (China).

[4] Joshua Fairfield, "Virtual Property" (2005) 85 B.U.L. Rev. 1047 at 1049.

[5] Black Snow Interactive and the World' s First Virtual Sweet Shop, JULIAN DIBBELL (Jan 2019), http:// 
juliandibbell.com/texts/blacksnow.html

[6] Blizzard End User License Agreement, North America (Jun. 1, 2018), https://www.blizzard.com/en-us/ legal/fba4d00f-c7e4-4883-b8b9-1b4500a402ea/blizzard-end-user-license-agreement

[7] Michael H. Passman, Transactions of Virtual Items In Virtual Worlds, Albany Law Journal of Science and Technology, 261-290, 268, https:// www.westlaw.com/Document/I2f794a998a8e11dd93e7a76b30106ace/View/FullText.html?transition Type $=$ Default $\&$ contextData $=($ sc. De fault) $\& \mathrm{VR}=3.0 \& \mathrm{RS}=$ cblt1.0.
[8] Reuben Grinberg, Bitcoin: An Innovative Alternative Digital Currency, 4 Hastings Sci. \& Tech. L.J. 159, 163 (2012). https://www.westlaw.com/Document/ Id470bb002b9e11e18b05fdf15589d8e8/View/FullText.html?transitionType $=$ Default\&contextData $=($ sc. Default $) \& V R=3.0 \& R S=$ cblt 1.0 .

[9] John D. Sutter, CNN, Can People actually 'own' virtual land? (May. 20, 2010), http://www.cnn. com/2010/TECH/05/10/virtual.property.second.life/ index.html. 